\title{
An Empirical Study on Impact of China's Outward Foreign Direct Investment on Export Commodity Structure Optimization
}

\author{
HU Wei-xuan ${ }^{1,2, ~ a, ~ L I N G ~ D a n ~}{ }^{1}$ \\ ${ }^{1}$ School of Economics, Wuhan University of Technology, Wuhan 430070, China \\ ${ }^{2}$ Wuhan Technical College of Communications, Wuhan 430065, China \\ ${ }^{a}$ E-mail:363612417@qq.com
}

Keywords: outward foreign direct investment (OFDI), export commodity structure, VAR model

\begin{abstract}
In order to explore whether outward foreign direct investment (OFDI) upgrades the home country's export commodity structure, the paper constructed the Vector Auto Regression (VAR) model to study the impact of China's OFDI on export commodity structure. The results show that OFDI does optimize the export commodity structure of China, which provides the empirical basis for government decision-makers to make trade policies and strategy.
\end{abstract}

\section{Introduction}

With the development of economic globalization, and scientific and technological progress as well as the deepening of the international division of labor, each country continues to increase the efforts of foreign investment. Since the reform and opening up, China embarked on the road of foreign direct investment, while attracting a large number of foreign direct investments and intensively development of foreign trade. Despite a late start, China's OFDI develops rapidly. Figure 1 shows the change in China's OFDI flow and stock from 1982 to 2012.

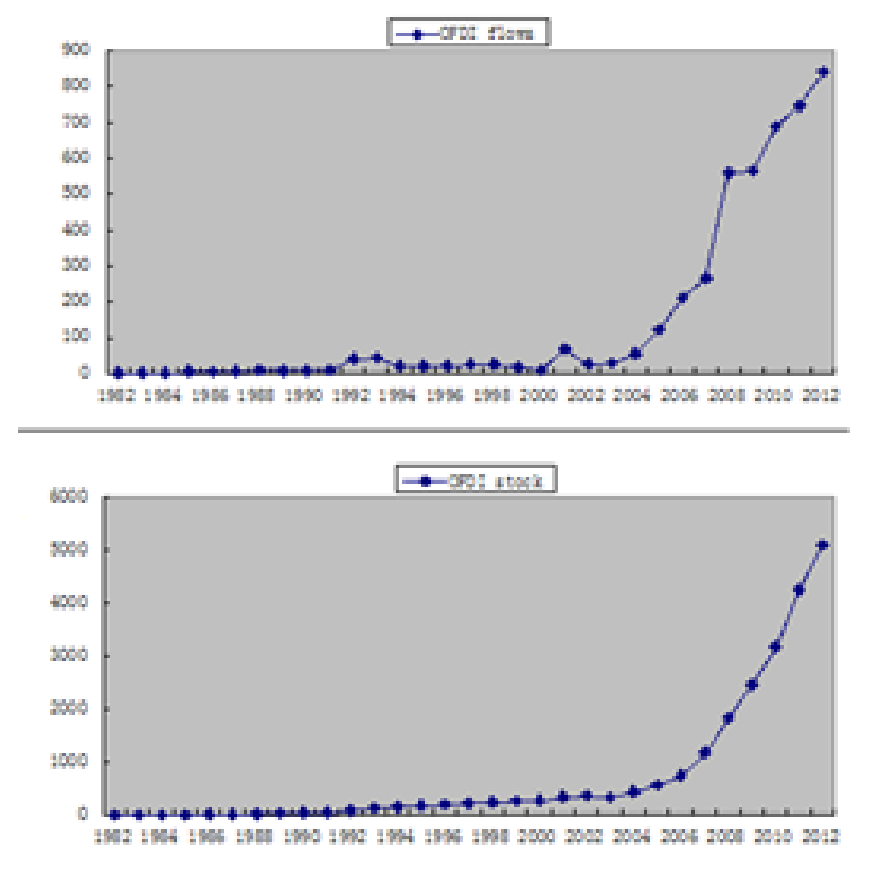

Fig. 1 China's OFDI flow and stock during 1982 and 2012 (hundred million USD)

Resources: UNCTAD

International trade and outward foreign direct investment (OFDI) are the main channels for a country's integration into the economic globalization, so what the mutual relationship between the two is and how to coordinate them in order to promote economic development of a country or region have become key issues for the government and economists to be solved. This paper is organized as 
follows: Existing literature is introduced in Section 2. In Section 3, how China's OFDI influence export commodity structure is described. Section 4 is the conclusion.

\section{Theoretical Background}

So far, there is no general agreement on the relationship of OFDI and export trade. The relevant theoretical researches present three perspectives: alternative effect, complementary effect and contingency effect [1]. As to the alternative effect, Mundell (1957) mathematically modeled cross-border capital flows in a Heckscher-Ohlin framework, Buckley and Casson (1976) commented the theory of internalization, Dunning (1978) raised an eclectic paradigm and continued to update the theory. As to the complementary effect, Kojima (1973rasied marginal industry expansion theory, Tolentino (1993) and Cantwell (1994) put forward the technological innovation. Further evidence is in favor of contingency effect [2]. The determinants in the relationship of OFDI and export trade are: the level of international investment(Bergsten et al,1980), the cooperation between trade and non-trade elements(Markuson and Svenson,1985), the market-oriented OFDI or the productivity-oriented OFDI(Gray,1998), the vertical investment or horizontal investment(Head and Ries,2001),short-term or long-term effect of investment(Blonigen,2001), the degree of industrial classification(Svenson,2004),industrial structure, domestic investment, balance of payments, advance in technology, the political decision-making in the home country (Kokko,2006).

Most of these studies focus on the relationship between OFDI and foreign trade, whether OFDI can enhance the home country's structure of export products or not is not enough.

\section{The Empirical Analysis}

\section{Data and Descriptive Statistics}

Model variables include:

A.The proportion of China's foreign direct investment (stock) in GDP recorded as RIG represents the relative size of foreign direct investment and reflects the level of openness of China's economy.

Table 1 RIG during 1982 and 2012

\begin{tabular}{llllllll}
\hline year & $\begin{array}{l}\text { OFDI } \\
\text { (hundred }\end{array}$ & $\begin{array}{l}\text { GDP } \\
\text { (hundred }\end{array}$ & $\begin{array}{l}\text { RIG } \\
\text { (OFDI/GDP) }\end{array}$ & year & $\begin{array}{l}\text { OFDI } \\
\text { (hundred } \\
\text { million USD) }\end{array}$ & $\begin{array}{l}\text { GDP } \\
\text { (hundred }\end{array}$ & $\begin{array}{l}\text { RIG } \\
\text { (OFDI/GDP) USD) }\end{array}$ \\
\hline 1982 & 0.44 & 2953.7 & 0.0001 & 1998 & 250.78 & 10451.99 & 0.0240 \\
1983 & 1.37 & 3146.37 & 0.0004 & 1999 & 268.53 & 11007.76 & 0.0244 \\
1984 & 2.71 & 3173.52 & 0.0009 & 2000 & 277.68 & 11928.36 & 0.0233 \\
1985 & 9 & 3090.83 & 0.0029 & 2001 & 346.54 & 13172.3 & 0.0263 \\
1986 & 13.5 & 3043.48 & 0.0044 & 2002 & 371.72 & 14555.54 & 0.0255 \\
1987 & 19.95 & 3298.51 & 0.0060 & 2003 & 332.22 & 16507.7 & 0.0201 \\
1988 & 28.45 & 4134.39 & 0.0069 & 2004 & 447.77 & 19427.81 & 0.0230 \\
1989 & 36.25 & 4597.82 & 0.0079 & 2005 & 572.06 & 22836.71 & 0.0251 \\
1990 & 44.55 & 4044.94 & 0.0110 & 2006 & 750.26 & 27872.54 & 0.0269 \\
1991 & 53.68 & 4241.17 & 0.0127 & 2007 & 1179.11 & 34943.51 & 0.0338 \\
1992 & 93.68 & 4998.59 & 0.0187 & 2008 & 1839.71 & 45318.31 & 0.0406 \\
1993 & 137.68 & 6410.69 & 0.0215 & 2009 & 2457.55 & 50694.7 & 0.0485 \\
1994 & 157.68 & 5826.53 & 0.0271 & 2010 & 3172.11 & 59514.62 & 0.0533 \\
1995 & 177.68 & 7569.6 & 0.0235 & 2011 & 4247.81 & 72037.84 & 0.0590 \\
1996 & 198.82 & 8920.14 & 0.0223 & 2012 & 5090.01 & 80943.62 & 0.0629 \\
1997 & 224.44 & 9850.46 & 0.0228 & & & & \\
\hline
\end{tabular}

Resources: Calculated from data obtained from UNCTAD

B. Chinese export commodities trade competitiveness index (abbreviated: TC) represents the performance of export products in the international market. Furthermore, according to the standard international trade classification (SITC), the Chinese export goods in SITC0-4 are regarded as resource-intensive products, SITC6, 8, 9 regrade as labor-intensive products, SITC5, 7 regraded as 
capital and technology intensive products, the trade competitiveness indexes of the three sorts are recorded as TCR, TCL, and TCK.

According to trade competitiveness index (TC) formula:

$$
T C_{i}=\left(E_{i}-I_{i}\right) /\left(E_{I}+I_{i}\right)
$$

Where $E_{i}$ is the total exports of product $i, I_{i}$ is the total imports of the product $i$. If the trade competitiveness index is positive, it means that the country is a net supplier of $\mathrm{i}$, production efficiency of this product is higher than the international level. The more TC closes to 1, the stronger the international competitiveness of the sort of products; otherwise weaker.

Calculated TCR,TCL,TCK, as shown in Table 2.

Table 2 TCR, TCK, and TCL during 1982 and 2012

\begin{tabular}{llllllll}
\hline year & TCR & TCK & TCL & year & TCR & TCK & TCL \\
\hline 1982 & 0.1366 & -0.4281 & 0.2807 & 1998 & -0.0566 & -0.1197 & 0.4364 \\
1983 & 0.2471 & -0.4873 & 0.0929 & 1999 & -0.1476 & -0.1492 & 0.3997 \\
1984 & 0.3924 & -0.6015 & 0.0285 & 2000 & -0.2947 & -0.1266 & 0.3932 \\
1985 & 0.4467 & -0.8135 & 0.0159 & 2001 & -0.2692 & -0.1248 & 0.3829 \\
1986 & 0.3323 & -0.7582 & 0.0142 & 2002 & -0.2664 & -0.1060 & 0.3780 \\
1987 & 0.3135 & -0.6629 & 0.1425 & 2003 & -0.3528 & -0.0767 & 0.3326 \\
1988 & 0.1972 & -0.6403 & 0.1724 & 2004 & -0.4861 & -0.0386 & 0.3452 \\
1989 & 0.1539 & -0.5691 & 0.1685 & 2005 & -0.5015 & 0.0262 & 0.3857 \\
1990 & 0.1444 & -0.4320 & 0.2969 & 2006 & -0.5591 & 0.0601 & 0.4430 \\
1991 & 0.1169 & -0.4495 & 0.3001 & 2007 & -0.5961 & 0.1014 & 0.4581 \\
1992 & 0.1239 & -0.4148 & 0.3391 & 2008 & -0.6459 & 0.1459 & 0.4830 \\
1993 & 0.0795 & -0.4666 & 0.2234 & 2009 & -0.6423 & 0.1130 & 0.4249 \\
1994 & 0.0890 & -0.3866 & 0.3462 & 2010 & -0.6831 & 0.1077 & 0.4094 \\
1995 & -0.0639 & -0.2666 & 0.3941 & 2011 & -0.7147 & 0.1121 & 0.4092 \\
1996 & -0.0742 & -0.2450 & 0.3540 & 2012 & -0.7266 & 0.1286 & 0.4249 \\
1997 & -0.0888 & -0.1439 & 0.4313 & & & & \\
\hline Resources & Caculated & & & & &
\end{tabular}

Resources: Calculated from data obtained from UNCTAD

Unit Root Test

Time series analysis require the relevant time series to be stationary, otherwise may lead to "spurious regression"[3]. This paper uses unit root test model to judge the stationary of each time series. The Augmented Dickey and Fulled(ADF)test model is used for each variable unit root test. In order to eliminate the phenomenon of heteroscedasticity, the variables are transformed using natural log function and recorded as LNRIG.ADF unit root test results for each variable are shown in Table 3.

Table 3 ADF Text Result for Each Variable

\begin{tabular}{ccccccl}
\hline Variables & $\begin{array}{c}\text { Selection } \\
(\mathrm{C}, \mathrm{T}, \mathrm{K})\end{array}$ & ADFVaule & $\begin{array}{c}\text { Mackinnon } \\
\text { critical value } \\
\text { at1\%level }\end{array}$ & $\begin{array}{c}\text { Mackinnon } \\
\text { critical value } \\
\text { at5\%level }\end{array}$ & $\begin{array}{c}\text { Mackinno } \\
\text { critical value } \\
\text { at10\%level }\end{array}$ & Result \\
\hline TCR & $(\mathrm{C}, \mathrm{T}, 3)$ & -5.1907 & -4.2967 & -3.5684 & -3.2184 & Stationary $^{* * * *}$ \\
TCK & $(\mathrm{C}, \mathrm{T}, 3)$ & -3.5162 & -4.2967 & -3.5684 & -3.2184 & Stationary $^{*}$ \\
TCL & $(\mathrm{C}, \mathrm{T}, 3)$ & -2.8453 & -4.2967 & -3.5684 & -3.2184 & Non-stationary $^{*}$ \\
LNRIG & $(\mathrm{C}, \mathrm{T}, 3)$ & -6.8775 & -4.2967 & -3.5684 & -3.2184 & Stationary $^{* * *}$ \\
D(TCR) & $(\mathrm{C}, 0,4)$ & -6.2328 & -3.6793 & -2.9678 & -2.6230 & Stationary $^{* * *}$ \\
D(TCK) & $(\mathrm{C}, 0,4)$ & -3.9133 & -3.6793 & -2.9678 & -2.6230 & Stationary $^{* * *}$ \\
D(TCL) & $(\mathrm{C}, 0,4)$ & -6.1836 & -3.6793 & -2.9678 & -2.6230 & Stationary $^{* * *}$ \\
D(LNRIG) & $(\mathrm{C}, 0,4)$ & -3.5940 & -3.6793 & -2.9678 & -2.6230 & Stationary $^{* *}$ \\
\hline
\end{tabular}

Note: Selection $(\mathrm{C}, \mathrm{T}, \mathrm{K}), \mathrm{C}$ means constant means trends means different lagging order; D indicates differences; $* * *$ 、 ***represent the Mackinnon critical value at $10 \%, 5 \%, 1 \%$ significant level respectively. 
Test results as shown in Table 3 indicate that the ADF values of only one series of TCL is bigger than the critical value at any certain significant level, showing that there is root unit and it's not stationary. But the ADF test values of all the first order differential variable sequence D (TCR), D (TCK), D (TCL), D (LNRIG) are smaller than the critical value at any certain significant level, showing that there are not root units and they're stationary. Thus, we're sure that variables under test are the first-order difference stationary series, so that cointegration test can be carried out.

\section{Vector Auto-regression (VAR) Model}

The key of VAR is to select the suitable lag order number of variables. Calculating LR, FPE, AIC, SC and HQ of four indexes named TCR, TCK, TCL and LNRIG respectively through Eviews 6.0 in order to judge the optimal lag order number, the calculations are in Table 4.According to Table 4, only LR and AIC select 1 as the lag order, the other criterion all select 3, so VAR (3) model is established.

Table 4 the selection of VAR optimal lag order

\begin{tabular}{ccccccc}
\hline \hline Lag & LogL & LR & FPE & AIC & SC & HQ \\
\hline \hline 0 & 78.93825 & NA & $5.57 \mathrm{e}-08$ & -5.352732 & -5.162417 & -5.294551 \\
1 & 183.5237 & $171.8190^{\star}$ & $1.01 \mathrm{e}-10$ & -11.68027 & $-10.72869^{\star}$ & -11.38936 \\
2 & 201.9891 & 25.06011 & $9.16 \mathrm{e}-11$ & -11.85636 & -10.14353 & -11.33273 \\
3 & 222.5838 & 22.06575 & $8.17 \mathrm{e}-11^{*}$ & $-12.18455^{\star}$ & -9.710460 & $-11.42820^{\star}$ \\
\hline \hline
\end{tabular}

\footnotetext{
* indicates lag order selected by the criterion

LR: sequential modified LR test statistic (each test at $5 \%$ level)

FPE: Final prediction error

AIC: Akaike information criterion

SC: Schwarz information criterion

$\mathrm{HQ}$ : Hannan-Quinn information criterion
}

The next step is to examine whether the model satisfies the stability condition of VAR model. According to the root AR diagram method, if inverse roots of AR characteristic polynomial are less than 1 (locate in the unit circle), the model is stable ${ }^{[4]}$. From the Figure 2, we can find that all the inverse roots of AR characteristic polynomial are inside the unit circle. So 3 is regarded as the suitable lag order.

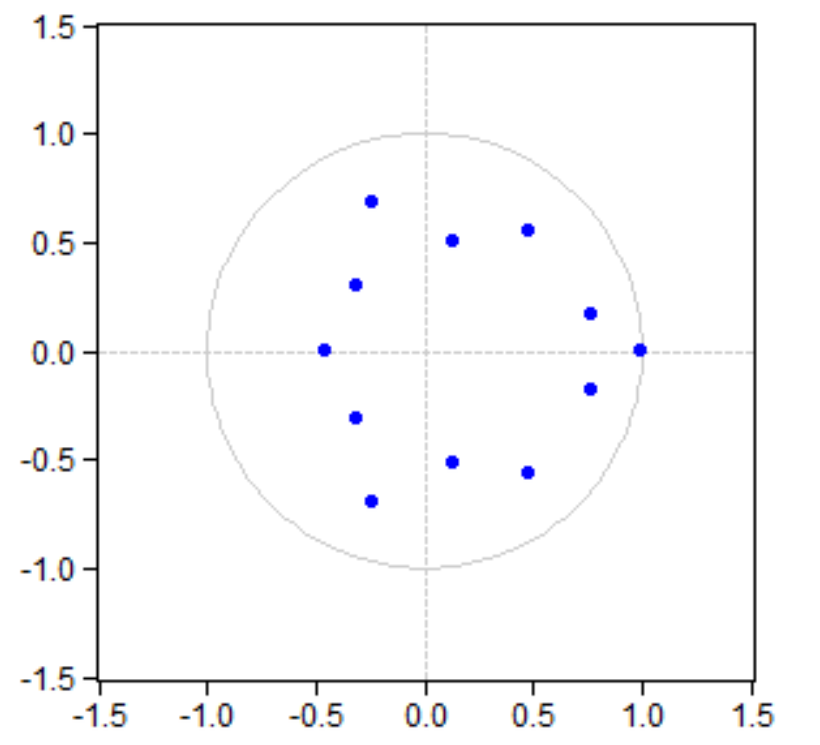

\section{Cointegration Test}

Fig. 2 Inverse Roots of AR Characteristic Polynomial

The cointegration test proposed by Johansen(1988,1991) and Johansen and Juselius(1990) is carried out to test the long-term stable relationship between China's OFDI and the structure of export products.Cointegration test results, as shown in table 5, indicate that there is one and only one cointegration equation existing between TCR and LNRIG and that there is one and only one cointegration equation existing between TCK and LNRIG, between TCL and LNRIG respectively,too. The cointegration vector of TCR and LNRIG is (1, -0.2033), and that of TCK and LNRIG is (1, 
0.3666), for the TCL and LNRIG is $(1,0.1405)$.Vector Error Correction estimates can be done accordingly between TCR and LNRIG,between TCK and LNRIG,between TCL and LNRIG respectively as shown in Table 6 .

Table 5 VAR (3)Johansen Cointegration Test

\begin{tabular}{ccccc}
\hline Hypo No. of CE(s) & Eigenvalue & Trace Statistics & 5\%Critical Value & Prob** \\
\hline None $^{*}$ & 0.7394 & 65.3965 & 47.8561 & 0.0005 \\
At most 1 & 0.4860 & 27.7062 & 29.7971 & 0.0855 \\
At most 2 & 0.2698 & 9.0707 & 15.4948 & 0.3589 \\
At most 3 & 0.0095 & 0.2664 & 3.8415 & 0.6057 \\
\hline
\end{tabular}

Note:*denotes rejection of the hypothesis at the $5 \%$ level

Table 6 Vector Error Correction Estimates

\begin{tabular}{cccccc}
\hline & \multicolumn{4}{|c|}{ Explanatory variables } \\
\cline { 2 - 5 } Explained variable & TCR & TCK & TCL & LNRIG \\
\hline TCR & 0 & -1.6419 & 2.2532 & -0.2033 \\
TCK & -1.0416 & 0 & -2.5001 & 0.3666 \\
TCL & 1.5294 & -1.7290 & 0 & 0.1405 \\
LNRIG & -0.5678 & 0.2833 & 0.1638 & 0 \\
\hline
\end{tabular}

\section{Conclusion}

In the article, we adopt VAR model in econometrics to study the relationship between China's OFDI and the structure of export products. With reference to the empirical analysis we obtain the following results: China's OFDI dose promote export of capital and technology-intensive products and labor-intensive products, but impose restrictions to the export of resource-intensive products. Specifically, with an increase of one percentage point in foreign direct investment, competition index of resource-intensive products exports fall $0.2033 \%$, and that of capital and technology-intensive products exports rise by 0.3666 percent, and that of labor-intensive products exports rise by $0.1405 \%$. The empirical study from the perspective of trade competitiveness found that China's OFDI improve the trade competitiveness of labor-intensive products and capital and technology-intensive products, but have a negative role in trade and competitiveness of resource-intensive products. The combined impact of OFDI on the trade competitiveness of these three products shows that it promotes China's export commodity optimization.

Acknowledgements: Supported by projects grant from Generalized Virtual Economy Research Institute, China (Grand No. GX2015-1011(Y)) and grant from Hubei Provincial Bureau of Statistics, China (Grand No. ETK15-47).

\section{References}

[1] Iwamoto Manabu, Nabeshima Kaoru. "Can FDI Promote Export Diversification and Sophistication of Host Countries? Dynamic Panel System GMM Analysis.” IDE Discussion Paper,No.347,2012.

[2] Robert A. Mundell. International Trade and Factor Mobility.The American Economic Review, Vol.47,No.3,1957: 321-335.

[3] Carmen Stoian. Extending Dining's Investment Development Path: the Role of Home Country Institutional Determinants in Explaining Outward Foreign Direct Investment. International Business Review, 2013, 22(3): 615-637.

[4] Kalman Kalotay, Astrit Sulstarova. Modelling Russian outward FDI. Journal of International Management, 2010(2): 131-142. 